\title{
Knowledge and Response of Iraqi People on Future Health Care Changes and Visiting Dental Clinics during and after COVID-19
}

\author{
Dler Ali Khursheed ${ }^{1, \odot}$ Aras Maruf Rauf ${ }^{2} \quad$ Fadil Abdullah Kareem ${ }^{2}$ Arass Jalal Noori ${ }^{2}$ \\ Mohammed Abdalla Mahmood ${ }^{3}$ Rukhosh Hassan Abdalrahim ${ }^{3}$
}

${ }^{1}$ Department of Periodontics, College of Dentistry, University of Sulaimani, Sulaymaniyah, Iraq

2Department of Pedodontics, Orthodontics and Preventive Dentistry, College of Dentistry, University of Sulaimani, Sulaymaniyah, Iraq

${ }^{3}$ Department of Dental Basic Sciences, College of Dentistry, University of Sulaimani, Sulaymaniyah, Iraq

Eur Dent Res Biomater J 2020;1:57-63

\begin{abstract}
Address for correspondence Dler A. Khursheed, BDS, MSc, HDD Periodontics, PGDip, University of Sulaimani, Sulaymaniyah 46001, Iraq (e-mail: dler.khursheed@univsul.edu.iq).
\end{abstract}

\begin{abstract}
Keywords

- health care system

- dental clinics

- vaccination

- COVID-19

- SARS-CoV-2

- Iraq

Objectives This article aimed to find out Iraqi people's opinions on possible dental health care changes and their knowledge, attitude, and expectation toward infection controls in dental settings during and after the coronavirus disease-2019 (COVID-19) pandemic.

Materials and Methods Different questions were presented regarding possible health care system changes, to gather people's opinions concerning patients, dentists, and dental clinic tests for contagious viral infections, their history of vaccination, and their readiness to get vaccinated, and finally, how they would feel about visiting their local dental clinics during the COVID-19 pandemic if they faced dental problems.

Results Generally, $69 \%$ of the respondents believed that the health care system will change in Iraq. A higher percentage of health care workers than nonhealth workers had been vaccinated against hepatitis virus and approximately equal numbers indicated their readiness to be vaccinated against COVID-19 and other contagious viral diseases. Additionally, a higher percentage of health care workers than Non health care workers expressed fear of contracting the infection from dental clinics and the relation was significant. More than two-thirds of respondents stated their inability to visit a dentist because all the dental clinics are closed, and they cannot find a trusted dental clinic. Likewise, the majority preferred to wait until after the outbreak or when the government provides strict control measures and guidelines for dental clinics.

Conclusion There was a common belief that the health care system will change after COVID-19 in Iraq. All agreed that dental clinics and the population should be protected against microbial cross-transmission through appropriate infection control measures and vaccination. Future health care changes should include public health education and dental health care personnel training.
\end{abstract}

DOI https://doi.org/ $10.1055 / \mathrm{s}-0040-1721621$.
(C) 2020. European Dental Research and Biomaterials Journal.

This is an open access article published by Thieme under the terms of the Creative Commons Attribution-NonDerivative-NonCommercial-License, permitting copying and reproduction so long as the original work is given appropriate credit. Contents may not be used for commercial purposes, or adapted, remixed, transformed or built upon. (https://creativecommons.org/licenses/by-nc-nd/4.0/)

Thieme Medical and Scientific Publishers Pvt. Ltd., A-12, 2nd Floor, Sector 2, Noida-201301 UP, India 


\section{Introduction}

Coronavirus disease-2019 (COVID-19) is an acute infection of the respiratory tract that appeared in late 2019 in China and is caused by the severe acute respiratory syndrome-coronavirus-2 (SARS-CoV-2). ${ }^{1}$ It is a highly communicable disease and spreads rapidly between people. Symptomatic, presymptomatic (1-14 incubation days), and asymptomatic patients can disseminate the virus. ${ }^{2,3}$ Transmission among family members, religious gatherings, and health care workers has been documented., ${ }^{4,5}$, The World Health Organization has stated that SARS-CoV-2 spreads primarily through droplets of saliva or discharge from the nose when an infected person coughs, sneezes, or speaks, particularly in enclosed environments (https://www. who.int/health-topics/coronavirus\#tab=tab_1) ${ }^{6,7}$ Literature evidence showed that the primary mode of transmission of SARS-CoV-2 is through direct or indirect inoculation of the mucous membranes (eyes, nose, or mouth) with infectious respiratory droplets or fomites. ${ }^{8}$ However, blood transmission is also possible. ${ }^{9}$

Infectious diseases have created a significant problem for the public health care system in many countries. ${ }^{10}$ Today's eco-epidemiology has led to the emergence and re-emergence of some new communicable microorganisms that pose a threat to humankind, SARS-CoV-2 being the most recent. ${ }^{11}$ In line with their past predictions, scientists are also expecting human beings to face new COVID-type infectious disease pandemics in future. ${ }^{12-14}$ This will disrupt and cripple the health care system again if appropriate preplanned measures are not taken.

Patients and dental health care workers (DHCWs) are at risk of cross-contamination in dental clinics by infectious agents such as viruses and bacteria, especially those related to respiratory tract infections, due to the generation of aerosols during various dental procedures. ${ }^{15,16}$ A study has shown that deaths among health care workers continue to rise. ${ }^{17}$ Now that COVID-19 has reached pandemic level and since there are as yet neither effective treatments nor vaccines, ${ }^{18}$ strict infection control measures remain the only way to prevent coronavirus from spreading among DHCWs and patients in dental settings. And this mandates appropriate health education and instructions among health care workers to prevent nosocomial transmission and maintain safe dental treatment.

Every country should think about the necessary precautions and modifications in their health system model to secure people from cross-infection and keep the health system functioning if another unusual infection outbreak occurs. COVID-19 has disrupted health care systems throughout the world. And in response, most countries, including Iraq, have activated telemedicine/teledentistry to provide tele-triage, established virtual clinics to minimize patient and medical staff contact, and opened a few local hospital clinics to provide treatment only for emergency and urgent cases, with strict infection control guidelines. ${ }^{12}$ On the other side, all elective therapies have been halted until further notice.
This study was conducted among Iraqi people to assess their level of health education, their vaccination history, and attitude toward being vaccinated, their opinion about the risk of contracting microbial SARS-CoV-2 infections in dental clinics, and how they believe the dental health care system will change in Iraq in the post-COVID era.

\section{Materials and Method}

This study was conducted among Iraqi people via an Internet-mediated questionnaire. Google Forms was used, and 20 questions were presented in three Iraqi formal languages: English, Arabic, and Kurdish. The title and objectives of the study were placed on the front page of the questionnaire in these three languages. For each language, all the questions were presented on the same page but categorized into four unseparated question groups: (A) There were four questions on demographic data, (B) two subsequent and interrelated questions on possible changes in the health care system after COVID-19 outbreaks, (C) assessment of general knowledge on contagious viral diseases and vaccination history, opinions on local dental clinics' disinfection provision, and (D) how respondents feel about visiting the dental clinic during the COVID-19 pandemic. Different closed- and open-ended questions were presented in dichotomous and trichotomous (multiple-choice questions), multiple-choice grid questions, and checkbox questions. The anonymity of respondents was protected by not asking for their identities or email addresses. The questionnaire was prepared by three of the authors and reviewed and edited by the other authors. Then, it was sent to two different translators to review and translate the questions. Finally, the questionnaire was submitted to the Medical Language Unit at the College of Dentistry, University of Sulaimani for final revision. The proposal for this electronic study was submitted to the scientific and ethical committees at the College of Dentistry and approval was obtained.

The respondents were limited to a single response to the questionnaire, that is, after the respondents' submission, no link was available to enable them to submit another form. Respondents were also unable to edit their reply after submission of the questionnaire. As we targeted the whole Iraqi population rather than a specific population, we decided to announce the questionnaire through the highest ranked social media platform in Iraq according to Alexa ranking, which is the Facebook platform (https://www.alexa.com/ topsites/countries/IQ). The announcement was posted for the following 5 days (April 7-11, 2020). The advertisement covered all of Iraq's cities.

\section{Statistical Analysis}

The collected data were analyzed by statistical software package SPSS 24 (SPSS Inc.; Chicago, Illinois, United States). Descriptive analysis included percent values, tables, and figures to describe the distribution of the responses. Chi-square analysis was used to test possible associations between the responses to the questions (attitude) and the medical 
proficiency background of the respondents. Statistical significance was set at $p<0.05$.

\section{Results}

Among 1,574 clicks on the link, 433 individuals filled in the questionnaire, which constituted $27.5 \%$ of the clickers. Arabic and Kurdish language each accounted for approximately $46 \%$ of responses and $8 \%$ of responses were in English. Male and female respondents comprised 55.2 and $44.8 \%$, respectively. The percentages of health care workers versus nonhealth care workers were 23.1 and $76.9 \%$, respectively.

About $69 \%$ of the respondents thought the health system will change after the COVID-19 pandemic. Changes in health education, changes in the quality of the health services, and changes in procedures for visiting hospitals were the changes most frequently mentioned by respondents as likely to happen in the post-COVID era ( - Fig. 1).

Relatively high percentages of both Health care workers and NHCWs thought that dental clinics are risky places for contracting contagious diseases; however, there was a significant association $(p=0.0017)$ related to the high percentage of the latter group that were doubtful. Both groups similarly agreed that every patient should get tested for viral infection before dental treatment and likewise dentists should be screened for the same reason periodically ( - Table $\mathbf{1}$ ). About $65 \%$ of HCWs reported a history of hepatitis vaccination, twice the percentage among NHCWs. Meanwhile, twice as many NHCWs as compared with HCWs had no history of vaccination and could not remember if they had been vaccinated, and the association was highly significant $(p=0.001)$.
However, among people in both groups who had not yet been vaccinated, the majority expressed their readiness to get vaccinated against hepatitis virus. Similarly, for COVID-19 disease vaccine, high percentages of both groups expressed their acceptance of getting vaccinated when a vaccine becomes available. High percentages of both groups (>90\%) would prefer the health authority to apply strong health restrictions on dental clinics and periodically check clinics for viral contamination in efforts to control contagious disease transmissions. About $45 \%$ of both groups agreed that patients should commit to complying with dental appointment schedules to avoid crowding. Additionally, there was a significant relationship in terms of the two groups' agreement on the necessity of allocating sufficient disinfection time between treating different patients.

About $90 \%$ of both groups rejected the idea of visiting dental clinics with poor quality of infection controls. Although the majority of both groups thought their local hospitals and clinics do not have standard infection controls, twice as many HCWs as compared with NHCWs did not think their local dental clinics have poor infection controls, a significant association. More than half of both groups expressed readiness to visit a clean and safe dental clinic during outbreaks if they face a dental problem. However, the majority of respondents indicated their uncertainty about the health care system's ability to provide safe dental treatment. NHCWs were more fearful of getting an infection if they visit dental clinics during the outbreak and the relation was significant in comparison with HCWs. More than two-thirds reported their inability to visit a dentist due to the fact that all dental clinics are closed, and they cannot find a trusted dental clinic. Likewise, the

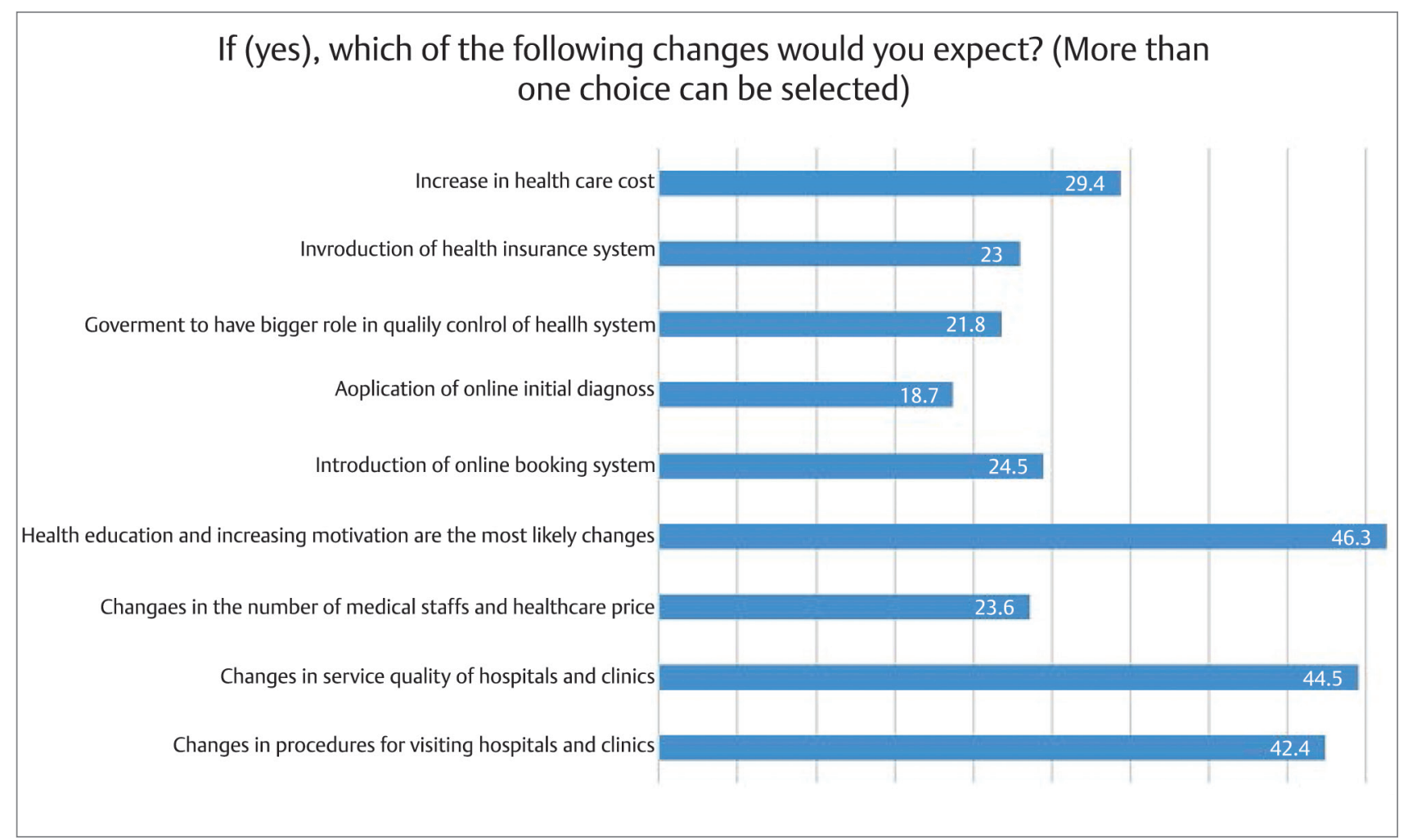

Fig. 1 Rankings of respondents' expectations in respect of possible changes in the Iraqi health system. 
Table 1 Questions on respondents' general knowledge on contagious diseases, vaccination, and quality of local dental clinics' disinfection procedures

\begin{tabular}{|c|c|c|c|c|c|}
\hline \multicolumn{2}{|l|}{ Questions } & \multicolumn{3}{|c|}{ Are you a health care worker? } & \multirow{4}{*}{$\begin{array}{l}\text { Chi-square } \\
\begin{array}{l}X^{2}(1, N=433)=0.528 \\
p=0.467\end{array}\end{array}$} \\
\hline & & Yes & No & Both & \\
\hline \multirow{2}{*}{$\begin{array}{l}\text { Do you think the health care system will } \\
\text { change after the coronavirus outbreak? }\end{array}$} & Yes & $72(72 \%)$ & $227(66.2 \%)$ & 299 (69.0\%) & \\
\hline & No & $28(28 \%)$ & $106(31.2 \%)$ & $134(30.9 \%)$ & \\
\hline \multirow{3}{*}{$\begin{array}{l}\text { Risk of contracting infectious diseases in } \\
\text { dental clinics is high: }\end{array}$} & Agree & $82(82 \%)$ & $230(69.0 \%)$ & $312(72 \%)$ & \multirow{3}{*}{$\begin{array}{l}X^{2}(1, N=433)=8.114 \\
p=0.0173\end{array}$} \\
\hline & Disagree & $6(6 \%)$ & $18(5.4 \%)$ & $24(5.54 \%)$ & \\
\hline & Maybe & $12(12 \%)$ & 85 (25.5\%) & $97(22.4 \%)$ & \\
\hline \multirow{3}{*}{$\begin{array}{l}\text { Do you agree every patient should get } \\
\text { tested for viral infections before visiting } \\
\text { dental clinics? }\end{array}$} & Yes & $78(78 \%)$ & $275(83 \%)$ & $353(82 \%)$ & \multirow{3}{*}{$\begin{array}{l}X^{2}(1, N=433)=2.663 \\
p=0.264\end{array}$} \\
\hline & No & $15(15 \%)$ & $31(9 \%)$ & $46(11 \%)$ & \\
\hline & Maybe & $7(7 \%)$ & $27(8 \%)$ & $34(7 \%)$ & \\
\hline \multirow{3}{*}{$\begin{array}{l}\text { Would you prefer every dentist to get } \\
\text { tested periodically for viral infection and } \\
\text { vaccination? }\end{array}$} & Yes & $92(92 \%)$ & $310(93 \%)$ & $402(93 \%)$ & \multirow{3}{*}{$\begin{array}{l}x^{2}(1, N=433)=4.317 \\
p=0.115\end{array}$} \\
\hline & No & $6(6 \%)$ & $8(2 \%)$ & $14(3 \%)$ & \\
\hline & Maybe & $2(2)$ & $15(6 \%)$ & $17(4 \%)$ & \\
\hline \multirow{3}{*}{$\begin{array}{l}\text { Have you been vaccinated against viral } \\
\text { diseases such as hepatitis virus? }\end{array}$} & Yes & $65(65 \%)$ & $109(32 \%)$ & $174(40 \%)$ & \multirow{3}{*}{$\begin{array}{l}X^{2}(1, N=433)=33.675 \\
p=0.0001\end{array}$} \\
\hline & No & $24(24 \%)$ & $139(42 \%)$ & $163(38 \%)$ & \\
\hline & I don't remember & $11(11 \%)$ & $85(26 \%)$ & $96(22 \%)$ & \\
\hline \multirow{3}{*}{$\begin{array}{l}\text { If No, would you and your family be } \\
\text { ready to get vaccinated? }\end{array}$} & Yes & $45(80 \%)$ & $227(75.6 \%)$ & $272(78.8)$ & \multirow{3}{*}{$\begin{array}{l}X^{2}(1, N=433)=3.382 \\
p=0.184\end{array}$} \\
\hline & No & $5(8.9 \%)$ & $15(5 \%)$ & $20(5.7 \%)$ & \\
\hline & Maybe & $6(10.7 \%)$ & $58(19 \%)$ & $64(18.5 \%)$ & \\
\hline \multirow{3}{*}{$\begin{array}{l}\text { If a coronavirus vaccine becomes } \\
\text { available, will you be ready to get } \\
\text { vaccinated? }\end{array}$} & Yes & $78(78 \%)$ & $268(80 \%)$ & $346(80 \%)$ & \multirow{3}{*}{$\begin{array}{l}X^{2}(1, N=433)=1.002 \\
p=0.605\end{array}$} \\
\hline & No & $7(7 \%)$ & $15(5 \%)$ & $22(5 \%)$ & \\
\hline & Maybe & $15(15 \%)$ & $50(15 \%)$ & $65(15 \%)$ & \\
\hline \multirow{3}{*}{$\begin{array}{l}\text { Would you prefer health authorities to } \\
\text { check every dental clinic periodically for } \\
\text { viral contamination? }\end{array}$} & Yes & $94(94 \%)$ & $311(93 \%)$ & 405 (94\%) & \multirow{3}{*}{$\begin{array}{l}X^{2}(1, N=433)=1.239 \\
p=0.538\end{array}$} \\
\hline & No & $4(4 \%)$ & $9(3 \%)$ & $13(3 \%)$ & \\
\hline & I don't know & $2(2 \%)$ & $13(4 \%)$ & $15(4 \%)$ & \\
\hline \multirow{4}{*}{$\begin{array}{l}\text { After this outbreak, based on which } \\
\text { of these reasons will patients be more } \\
\text { committed to complying with } \\
\text { appointment schedules? }\end{array}$} & Avoid crowding & $45(45 \%)$ & $149(44.7 \%)$ & $194(44.8 \%)$ & \multirow{4}{*}{$\begin{array}{l}X^{2}(1, N=433)=0.881 \\
p=0.830\end{array}$} \\
\hline & $\begin{array}{l}\text { Avoid being } \\
\text { penalized }\end{array}$ & $2(2 \%)$ & $11(3.3 \%)$ & $13(3 \%)$ & \\
\hline & Both & $20(20 \%)$ & $74(22.3 \%)$ & $94(21.7 \%)$ & \\
\hline & None will happen & $33(33 \%)$ & $99(29.7)$ & $132(30.5 \%)$ & \\
\hline \multirow{3}{*}{$\begin{array}{l}\text { Is it necessary to have adequate } \\
\text { disinfection time after each patient's } \\
\text { treatment at a dental clinic? }\end{array}$} & Yes & $93(93 \%)$ & $273(82 \%)$ & $366(85 \%)$ & \multirow{3}{*}{$\begin{array}{l}X^{2}(1, N=433)=7.206 \\
p=0.027\end{array}$} \\
\hline & No & $4(4 \%)$ & $30(9 \%)$ & $34(8 \%)$ & \\
\hline & I don't know & $3(3 \%)$ & $30(9 \%)$ & $33(7 \%)$ & \\
\hline \multirow{3}{*}{$\begin{array}{l}\text { Are you ready to visit a clinic that } \\
\text { does not have standard health } \\
\text { controls in place? }\end{array}$} & Yes & $6(6 \%)$ & $21(6 \%)$ & $27(6 \%)$ & \multirow{3}{*}{$\begin{array}{l}X^{2}(1, N=433)=2.061 \\
p=0.357\end{array}$} \\
\hline & No & $92(92 \%)$ & $294(88 \%)$ & $386(89 \%)$ & \\
\hline & Maybe & $2(2 \%)$ & $18(6 \%)$ & $20(5 \%)$ & \\
\hline Do you think your local hospital and & Yes & $73(73 \%)$ & $266(80 \%)$ & $339(78 \%)$ & $X^{2}(1, N=433)=8.573$ \\
\hline $\begin{array}{l}\text { dental clinics have poor infection } \\
\text { control? }\end{array}$ & No & $16(16 \%)$ & $22(7 \%)$ & $38(9 \%)$ & \\
\hline & I don't know & $11(11 \%)$ & $45(13 \%)$ & $56(13 \%)$ & \\
\hline Would you prefer health authorities & Yes & $95(95 \%)$ & $304(91 \%)$ & $399(92 \%)$ & $X^{2}(1, N=433)=1.573$ \\
\hline $\begin{array}{l}\text { to be responsible for imposing } \\
\text { regulations on dental clinics for }\end{array}$ & No & $2(2 \%)$ & $9(3 \%)$ & $11(3 \%)$ & \\
\hline controlling contagious diseases? & I don't know & $3(3 \%)$ & $20(7 \%)$ & $23(5 \%)$ & \\
\hline Has this questionnaire given you any & Yes & $63(63 \%)$ & $267(80 \%)$ & $330(76 \%)$ & $X^{2}(1, N=433)=12.521$ \\
\hline $\begin{array}{l}\text { new information on how to react when } \\
\text { visiting dental clinics in the future? }\end{array}$ & No & $37(37 \%)$ & $66(20 \%)$ & $103(24 \%)$ & \\
\hline & Totals & 100 & 333 & 433 & \\
\hline
\end{tabular}


Table 2 Respondents' attitudes toward visiting dental clinics during the COVID-19 pandemic

\begin{tabular}{|c|c|c|c|c|c|c|}
\hline \multicolumn{2}{|l|}{ Questions } & \multirow{2}{*}{$\begin{array}{l}\text { Answers } \\
\text { Yes }\end{array}$} & \multicolumn{3}{|c|}{ Are you a medical professional? } & \multirow{3}{*}{$\begin{array}{l}\text { Chi-square } \\
\begin{array}{l}X^{2}(1, N=433)=3.171, \\
p=0.074\end{array}\end{array}$} \\
\hline \multirow{6}{*}{$\begin{array}{l}\text { If you have a dental } \\
\text { problem during the } \\
\text { outbreak, which of } \\
\text { these factors would } \\
\text { encourage you to visit a } \\
\text { dental clinic? }\end{array}$} & \multirow{2}{*}{$\begin{array}{l}\text { Dental clinics are clean } \\
\text { and safe }\end{array}$} & & $\begin{array}{l}\text { Yes } \\
65(65 \%) \\
\end{array}$ & $\begin{array}{l}\text { No } \\
183(55 \%) \\
\end{array}$ & $\begin{array}{l}\text { Total } \\
248(57 \%) \\
\end{array}$ & \\
\hline & & No & $35(35 \%)$ & $150(45 \%)$ & $185(43 \%)$ & \\
\hline & \multirow{2}{*}{$\begin{array}{l}\text { Dentists are taking care } \\
\text { of public health }\end{array}$} & Yes & $76(76 \%)$ & $205(62 \%)$ & $281(65 \%)$ & \multirow{2}{*}{$\begin{array}{l}X^{2}(1, N=433)=7.038 \\
p=0.008\end{array}$} \\
\hline & & No & $24(24 \%)$ & $128(38 \%)$ & $152(35 \%)$ & \\
\hline & \multirow{2}{*}{$\begin{array}{l}\text { I trust in our health } \\
\text { system }\end{array}$} & Yes & $31(31 \%)$ & $102(31 \%)$ & $133(31 \%)$ & \multirow{2}{*}{$\begin{array}{l}X^{2}(1, N=433)=0.005 \\
p=0.944\end{array}$} \\
\hline & & No & $69(69 \%)$ & $231(69 \%)$ & $300(69 \%)$ & \\
\hline \multirow{6}{*}{$\begin{array}{l}\text { If you have a dental } \\
\text { problem, which of these } \\
\text { factors would deter you } \\
\text { from visiting a dental } \\
\text { clinic? }\end{array}$} & \multirow[t]{2}{*}{ Fear of being infected } & Yes & $67(67 \%)$ & $263(79 \%)$ & $330(76 \%)$ & \multirow{2}{*}{$\begin{array}{l}X^{2}(1, N=433)=6.087 \\
p=0.014\end{array}$} \\
\hline & & No & $33(33 \%)$ & $70(21 \%)$ & $103(24 \%)$ & \\
\hline & \multirow{2}{*}{$\begin{array}{l}\text { I cannot find a proper } \\
\text { dental clinic, all are } \\
\text { closed }\end{array}$} & Yes & $66(66 \%)$ & $218(65 \%)$ & $284(66 \%)$ & \multirow{2}{*}{$\begin{array}{l}X^{2}(1, N=433)=0.010 \\
p=0.921\end{array}$} \\
\hline & & No & $34(34 \%)$ & $115(35 \%)$ & $149(34 \%)$ & \\
\hline & \multirow{2}{*}{$\begin{array}{l}\text { Better to wait until after } \\
\text { the outbreak, manage it } \\
\text { myself with painkillers }\end{array}$} & Yes & $78(78 \%)$ & $277(83 \%)$ & $355(82 \%)$ & \multirow{2}{*}{$\begin{array}{l}X^{2}(1, N=433)=1.399 \\
p=0.237\end{array}$} \\
\hline & & No & $22(22 \%)$ & $56(17 \%)$ & $78(18 \%)$ & \\
\hline
\end{tabular}

majority preferred to wait until after the outbreak or until the government provided strict control measures and guidelines ( - Table 2 ).

Regarding whether they viewed this questionnaire as educational in terms of future visits to dental clinics, the majority of NHCWs expressed that it contained new information and a significant association was found with health care profession background.

\section{Discussion}

Many prospective articles are expecting multiaspect changes after COVID-19 to the health care system in general and dental health care in particular. ${ }^{19-21}$ However, these changes will be affected by the differences between developing and developed countries. For instance, developing countries rarely have proper health insurance systems. ${ }^{22}$ Regarding Iraq, a report produced by the World Bank Group in February 2017 stated that "Iraq's health care capacity has been severely undermined by the effects of various wars, international sanctions, sectarian violence, political instability, and fiscal pressures." It also stated, "Access to health services is limited, and geographical disparities are significant. Poor organization and shortages of staff and medications are significant impediments to delivering adequate services in the primary healthcare centers (PHCCs)." ${ }^{23}$ Given that COVID-19 has strained the most excellent health care systems in the world, achieving the required improvements to the health care system will pose a major challenge for the Iraqi government. In the current study, among those who expected health system changes, changes in health education, quality of the health services, and procedures for visiting hospitals and clinics were considered the most likely. As none of these changes were mentioned by more than $50 \%$ of respondents, this may indicate respondents' lack of belief that such changes will happen.

Fear of cross-infection in dental clinics is ubiquitous among dentists and patients. ${ }^{24,25}$ Dental personnel are constantly at risk of being infected and therefore should take greater responsibility for prevention of and protection against microbial transmission. Undoubtedly, their fear has a scientific basis as the aerosols that are produced during dental procedures can spread large numbers of microorganisms from patients' mouths into the clinic environment ${ }^{26}$ that can subsequently be inhaled by dental personnel and the next dental patients and those accompanying them. If appropriate interventions are not undertaken, cumulative microbial contamination in the clinic space will occur and expose all dental personnel and patients to infection. In addition, if the instruments used and fomite surfaces are not managed properly, they could also transmit microbial infection. ${ }^{27}$ These routes of transmissions are particularly important in the case of the SARS-CoV. ${ }^{2,28}$ Historically, there has been increasing concern regarding infection control in dental clinics, notably after an American dentist infected a few of his patients with human immunodeficiency virus. ${ }^{29}$ Similar concerns relate to hepatitis and COVID-19 virus transmission in dental clinics. ${ }^{24}$ The majority of respondents in the current study, particularly among HCWs, believed that dental clinics are risky places for contracting infectious diseases. This belief could have led to their agreement that every patient should get tested for viral infections before visiting a dentist and there was even higher support for periodic viral screening for dentists and other dental personnel. Furthermore, the vast majority (94\%) would prefer the relevant authorities to check dental clinics for viral contamination.

Vaccines have a long history in preventing communicable viral diseases. In some countries, many viral diseases have been eliminated (https://www.cdc.gov/vaccines/parents/ diseases/forgot-14-diseases.html). Therefore, getting people to agree to vaccination is a main government responsibility in curbing microbial transmissions. About two-thirds of the HCWs and one-third of NHCWs confirmed that they had been vaccinated against hepatitis virus infection, while some NHCWs did not remember if they had been vaccinated. A strong association was found between the two groups, and this may be related to HCWs' knowledge about hepatitis 
diseases and the prevention mechanisms. But a higher percentage of those who had not themselves or whose families had not been vaccinated against hepatitis expressed their readiness to be vaccinated against hepatitis. This indicates that people may not be aware that such kinds of vaccine are available at local health centers. This signifies the immediate need for education and preparation of a systematic program to encourage Iraqi people to visit local health centers to get vaccinated based on regular appointments. Although neither specific treatments nor vaccines for coronavirus are yet available, ${ }^{30}$ approximately $80 \%$ of respondents expressed their readiness to be vaccinated when a coronavirus vaccine becomes available.

In Iraq, the health system is currently incapable of meeting patients' health needs or imposing proper control measures on the public and private health sectors to ensure patients' commitment to visit health care centers and clinics. Similar percentages of both groups expressed their commitment to visit dental clinics in compliance with prescheduled appointments. About $45 \%$ believed patients would be committed to avoiding crowding, while a small percentage believed people would be motivated by penalties for patients upon noncompliance with their dedicated appointment time. And approximately one-third believed that none of these changes would happen in the post-COVID time. These two latter results can be considered a reflection of people's poor opinion of the quality of health provision in Iraq and their belief in the unlikelihood of change.

It is essential to provide ultimate infection controls and patient management in terms of allocating sufficient time for room disinfection between dental patients (https://health. mo.gov/living/families/oralhealth/pdf/aerosol-issues.pdf). People do not want to visit a dental clinic with poor infection control. However, patients do not have the capability to assess the quality of infection control in clinics. It is, therefore, the responsibility of the government and relevant organizations to implement direct surveillance of the quality of infection control in dental clinics and hospitals.

Respondents expressed their readiness to visit clean dental clinics where dental personnel are providing proper hygienic measures to make patients feel secure regarding the safety of their dental treatment and to eliminate fear of contracting contagious diseases. However, in a related question they indicated their uncertainty about the quality of their local health care centers. In reality, people are afraid of visiting dental clinics if they experience dental problems during the outbreak, since dental clinics are risky places for getting infected with contagious microorganisms. Due to this risk and their inability to find trusted dental clinics, a high percentage of respondents would prefer to postpone their treatment until after the outbreak ends.

As part of this survey, it was considered important to send a message regarding raising people's awareness. We asked respondents if this questionnaire contained some new information that would change their minds about visiting a dentist in the future. A high significant relation was found between the two groups as a result of NHCWs having less general health information compared with the HCW group.

Since this study was conducted only for five consecutive days and on a single social media platform, only a small sample of Iraqi people's opinion was collected. Future clinical and laboratory investigations will be necessary to assess the current infection control level in private dental clinics and in hospital and academic dental settings. Based on those investigations the government could propose and apply the necessary changes to strengthen people's trust in their health care system.

\section{Conclusion}

This survey demonstrated a common belief in the need for health care system change after COVID-19 in Iraq, but the prospects for such change are unclear. Making dental clinics safe and minimizing the risk to the population of microbial cross-transmission through appropriate infection control measures and vaccination should be the government's priority. Of course, it is also the responsibility of the government to allocate proper funding for education, research, and applied sciences to improve social and health welfare. Prevention of communicable diseases requires appropriate health care provision for the population, especially in dental clinics, hospitals, and academic settings. Although a larger-scale survey is needed to draw solid conclusions, this study can provide the government with critical information on how to revise and redesign its health care system, taking into account of its current health care circumstances and the advanced health care systems of other countries to step up to challenges posed by the next possible outbreak.

\section{Funding \\ None. \\ Conflict of Interest \\ None declared.}

\section{References}

1 Zhu N, Zhang D, Wang W, et al; China Novel Coronavirus Investigating and Research Team. A novel coronavirus from patients with pneumonia in China, 2019. N Engl J Med 2020; 382(8):727-733

2 Peng X, Xu X, Li Y, Cheng L, Zhou X, Ren B. Transmission routes of 2019-nCoV and controls in dental practice. Int J Oral Sci 2020;12(1):9

3 Azim AA, Shabbir J, Khurshid Z, Zafar MS, Ghabbani HM, Dummer PMH. Clinical endodontic management during the COVID-19 pandemic: a literature review and clinical recommendations. Int Endod J 2020;53(11):1461-1471

4 Chan JF-W, Yuan S, Kok K-H, et al. A familial cluster of pneumonia associated with the 2019 novel coronavirus indicating person-to-person transmission: a study of a family cluster. Lancet 2020;395(10223):514-523

5 Sabino-Silva R, Jardim ACG, Siqueira WL. Coronavirus COVID-19 impacts to dentistry and potential salivary diagnosis. Clin Oral Investig 2020;24(4):1619-1621

6 Stadnytskyi V, Bax CE, Bax A, Anfinrud P. The airborne lifetime of small speech droplets and their potential 
importance in SARS-CoV-2 transmission. Proc Natl Acad Sci U S A 2020;117(22):11875-11877

7 Lewis D. Is the coronavirus airborne? Experts can't agree. Nature 2020;580(7802):175

8 Otter JA, Donskey C, Yezli S, Douthwaite S, Goldenberg SD, Weber DJ. Transmission of SARS and MERS coronaviruses and influenza virus in healthcare settings: the possible role of dry surface contamination. J Hosp Infect 2016;92(3): 235-250

9 Chang L, Yan Y, Wang L. Coronavirus disease 2019: coronaviruses and blood safety. Transfus Med Rev 2020;34(2):75-80

10 Moradi Khanghahi B, Jamali Z, Pournaghi Azar F, Naghavi Behzad M, Azami-Aghdash S. Knowledge, attitude, practice, and status of infection control among Iranian dentists and dental students: a systematic review. J Dent Res Dent Clin Dent Prospect 2013;7(2):55-60

11 Ibrahim NK, Alwafi HA, Sangoof SO, Turkistani AK, Alattas BM. Cross-infection and infection control in dentistry: knowledge, attitude and practice of patients attended dental clinics in King Abdulaziz University Hospital, Jeddah, Saudi Arabia. J Infect Public Health 2017;10(4):438-445

12 Smith AC, Thomas E, Snoswell CL, et al. Telehealth for global emergencies: Implications for coronavirus disease 2019 (COVID-19). J Telemed Telecare 2020;26(5):309-313

13 Harapan H, Itoh N, Yufika A, et al. Coronavirus disease 2019 (COVID-19): a literature review. J Infect Public Health 2020; 13(5):667-673

14 Fan Y, Zhao K, Shi Z-L, Zhou P. Bat coronaviruses in China. Viruses 2019;11(3):E210

15 González-Olmo MJ, Ortega-Martínez AR, Delgado-Ramos B, Romero-Maroto M, Carrillo-Diaz M. Perceived vulnerability to coronavirus infection: impact on dental practice. Braz Oral Res 2020;34:e044

16 Hamid H, Khurshid Z, Adanir N, Zafar MS, Zohaib S. COVID-19 pandemic and role of human saliva as a testing biofluid in point-of-care technology 2020. Eur J Dent 2020;14(suppl S1):S123-S129 doi:10.1055/s-0040-1713020

17 Kursumovic E, Lennane S, Cook TM. Deaths in healthcare workers due to COVID-19: the need for robust data and analysis. Anaesthesia 2020;75(8):989-992

18 Lai C-C, Liu YH, Wang C-Y, et al. Asymptomatic carrier state, acute respiratory disease, and pneumonia due to severe acute respiratory syndrome coronavirus 2 (SARS-CoV-2): facts and myths. J Microbiol Immunol Infect 2020;53(3):404-412
19 Aboalshamat KT. Awareness of, beliefs about, practices of, and barriers to teledentistry among dental students and the implications for Saudi Arabia Vision 2030 and coronavirus pandemic. J Int Soc Prev Community Dent 2020;10(4):431-437

20 Barabari P, Moharamzadeh K. Novel coronavirus (COVID-19) and dentistry-a comprehensive review of literature. Dent J (Basel) 2020;8(2):E53

21 Martins MD, Carrard VC, Dos Santos CM, Hugo FN. COVID-19-are telehealth and tele-education the answers to keep the ball rolling in Dentistry? Oral Dis 2020. Doi: 10.1111/ odi. 13527

22 O'Donnell O. Access to health care in developing countries: breaking down demand side barriers. Cad Saude Publica 2007;23(12):2820-2834

23 Organization WH, Cleaning and Disinfection of Environmental Surfaces in the Context of COVID-19: Interim Guidance, 15 May 2020. World Health Organization; 2020

24 Singh BP, Khan SA, Agrawal N, Siddharth R, Kumar L. Current biomedical waste management practices and cross-infection control procedures of dentists in India. Int Dent J 2012; 62(3):111-116

25 Imran E, Khurshid Z, M Al Qadhi AA, A Al-Quraini AA, Tariq K. Preprocedural use of povidone-iodine mouthwash during dental procedures in the COVID-19 pandemic. Eur J Dent 2020;14(suppl S1):S182-S184 doi:10.1055/s-0040-1717001

26 Ahmed MA, Jouhar R, Ahmed N, et al. Fear and practice modifications among dentists to combat novel coronavirus disease (COVID-19) outbreak. Int J Environ Res Public Health 2020;17(8):E2821

27 Prasanth T, Mandlik VB, Kumar S, Jha AK, Kosala M. Evaluation of aerosol and water contamination and control of cross infection in dental clinics. Med J Armed Forces India 2010; 66(1):37-40

28 Khurshid Z, Asiri FYI, Al Wadaani H. Human saliva: non-invasive fluid for detecting novel coronavirus (2019-nCoV). Int J Environ Res Public Health 2020;17(7):E2225

29 Centers for Disease Control (CDC). Update: transmission of HIV infection during invasive dental procedures-Florida. MMWR Morb Mortal Wkly Rep 1991;40(23):377-381

30 Sarfaraz S, Shabbir J, Mudasser MA, et al. Knowledge and attitude of dental practitioners related to disinfection during the COVID-19 pandemic. Healthcare (Basel) 2020;8(3):E232 